\title{
STUDY ON ENHANCING THE ENERGY EFFICIENCY THROUGH REAL-TIME SMART ENERGY MANAGEMENT SYSTEMS FOR ACHIEVING GREEN ICT CAMPUS
}

Kesava Rao Alla Linton University College E-mail: alla@ieee.org

Zainuddin Hassan College of Information Technology, University Tenaga Nasional E-mail: zainuddin@uniten.edu.m

Soong Der Ghen Graphics and Multimedia Dept., College of Information Technology, University Tenaga Nasional E-mail: chensoong@uniten.edu.my

Recepción: 02/08/2019 Aceptación: 26/09/2019 Publicación: 06/11/2019

Citación sugerida:

Rao Alla, K., Hassan, Z. y Der Chen, S. (2019). Study on Enhancing the Energy Efficiency through Real-Time Smart Energy Management Systems for Achieving Green ICT Campus. 3C Tecnología. Glosas de innovación aplicadas a la pyme. Edición Especial, Noviembre 2019, 329-347. doi: http:// dx.doi.org/10.17993/3ctecno.2019.specialissue3.329-347

\section{Suggested citation:}

Rao Alla, K., Hassan, Z. \& Der Chen, S. (2019). Study on Enhancing the Energy Efficiency through Real-Time Smart Energy Management Systems for Achieving Green ICT Campus. 3C Tecnología. Glosas de innovación aplicadas a la pyme. Speciaal Issue, November 2019, 329-347. doi: http://dx.doi.org/10.17993/3ctecno.2019.specialissue3.329-347 


\section{ABSTRACT}

Most Higher Education Institutions (HEI) are trying to achieve a Green ICT Campus as part of its responsibility for building a sustainable environment. Efficient energy distribution is one of the key factors to achieve the maximum benefits of producing clean and green energy. The importance of renewable energy generation and distribution synchronized by ICT for achieving a green campus in Malaysian Higher Education Institution (MHEI) are suggested and discussed here. This research paper focuses on studying the current practices in energy usage in MHEI and proposing various techniques to reduce the consumption of energy usage to achieve Green ICT Campus through the Smart Grid including suggesting for alternate energy production. The obtained results show that the energy consumption was reduced to a significant level of $30 \%$ when tested for one HEI, which plays a key role in fulfilling the green computing requirements and provides a pathway to realizing a green campus. With these findings, it is envisaged that this system optimizes energy usage and could be applicable for any MHEI.

\section{KEYWORDS}

Smart Grid, Energy optimization, Green ICT Campus, Green Computing. 


\section{INTRODUCTION}

Mankind is completely dependent on an uninterrupted supply of energy for living and working. It has become the key ingredient in all sectors of modern economies. Millions of years ago, fossil fuels were formed on planet earth gradually through the organisms that were buried in swamps. Fossil fuels continue to be consumed massively and are expected to reach its last drop within this century based on the projected consumption and growth rates which is as follows: It is predicted that oil will run out in 53 years, natural gas in 54 years, and coal in 110 years from 2015 (Singh, 2017). This study also indicated that renewable and clean energies are the only alternative to the impending destruction of the world's economies through climate changes that are caused by the consumption of fossil fuels. This destruction is also leading to the overall rise in temperature of the planet which is expected to rise by 2 degrees within this century. It is important that the policies that are made towards renewable energy production and climate change at national level to reach institutions and every home to make the implementation cycle complete for the benefit of our planet.

Hence, this research paper focuses on the study of the energy demands of Higher Education Institutions in Malaysia to conserve adequate resources that are essential in building a greener society. Higher Education Institutions are a replica of a mini society with higher energy demands mainly due to the nature of its academic activities like teaching and learning, research endeavors and residential energy needs. Energy consumption of academic activities could be improved by installing smart equipment or following smart strategies in energy production and distribution. According to Ministry of Higher Education, Malaysia has more than 600 higher education institutions in private, semi-government and public sectors and the population that is involved with these institutions represent a substantial segment of the society (Ministry of Higher Education Malaysia, 2017). Modern Higher Education Institutes are one of the biggest energy consumers along with their growing demand for sophisticated technical infrastructure. The staff, students and the total community in today's HEI matches a populated town and any policies and strategies implemented in HEI's has a direct and indirect impact on the society due to its reach and the involvement of stakeholders (Howlett, Ferreira \& Blomfield, 2016). As HEI resemble the same nature 
in terms of operation and functionality, one Malaysian Higher Education institution has been selected to study the real-time energy consumption and distribution methods to optimize energy consumption.

\section{SUSTAINABLE DEVELOPMENT}

Development which embraces the needs of the existing without conceding the ability of next generations in accomplishing their requirements was the first broadly agreed term on sustainable development in the history of mankind in the UN Conference on the Human Environment, Stockholm, 1972. The modern world since the industrial revolution has needed larger amounts of energy for its growth and development. Extraction of fossil fuels for energy and consuming the fossil fuels for growth and development has entered new heights from the 20th century. Fossil fuels formed in the crests of the earth since millions of years are being consumed daily for energy production. Fossil fuel extraction, production and consumption began through burning the coal around 4000BC in China and oil and gas from 1800AD onwards (Ritchie \& Roser, 2017). The global fuel consumption is shown in Figure 1.

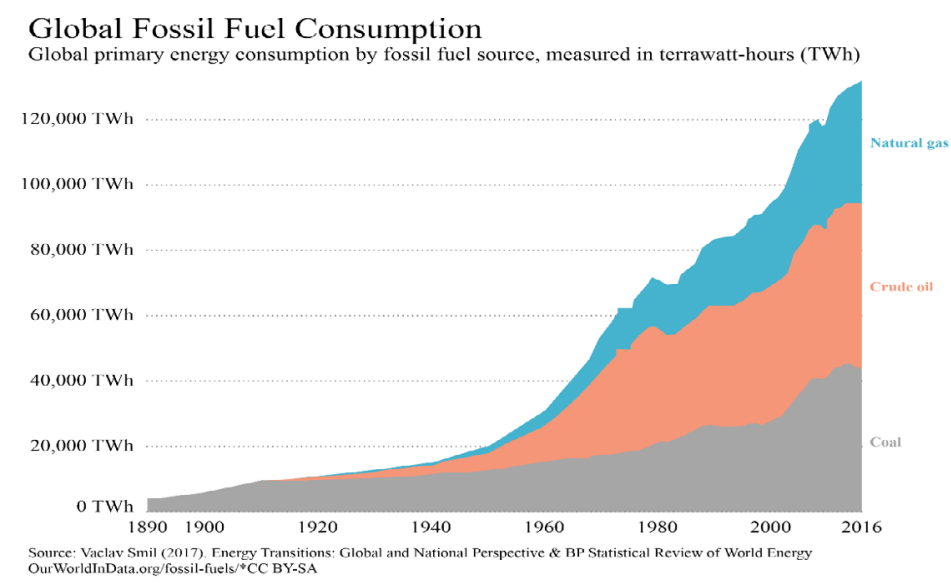

Figure 1. Fossil Fuel consumption chart.

It is surprising to see that these millions of year's fossil fuel reserves are being consumed within two centuries. The research analysis results show that, within another 50 years, the last drop of oil will be extracted from the earth at the present consumption 
ratio. But there is no concrete alternative that is equal and reliable to supplant this natural energy resource which is the fact as of today in 2017. Scientists have noticed this imminent disaster and started warning the mankind from the Nineteenth century (Du Pisani, 2006). The excessive urbanization and industrialization without maintaining an equilibrium with nature are leading mankind towards destruction. Whenever this symmetry is disturbed, there are consequences and at times, deadly consequences. The classic example of such an excessive usage of disturbing this ecological equipoise is visible in terms of natural disasters like unusual climatic conditions, global warming, disturbed patterns of el-Ninos, cyclones, and typhoons.

The scientific community has alerted this inhibiting danger and there are series of efforts by individuals, nations, social organizations and many other forms that joined hands together to overcome this melancholy. The first such major event was held in 1991 at Rio de Janeiro which gained a global reputation. Even though Brundtland Commission in 1987 was set up on studying the ecological disorders, it was the Rio declaration that provided the common guidelines and congregated the works of individuals and nations at the forefront in bringing up the efforts together. That noble task commenced in 1991, is still in progress and pleading our constant attention as of today. Rio declaration investigated major aspects of sustainable development and the causes of the environmental issues that are being faced by the mankind.

Energy generation is on one hand and the efficient distribution of the energy is on another hand which is equally important too. Energy distribution with smart grids and intelligent equipment that understands and performs the tasks with lesser human interaction without causing any inconvenience to the user are required to support the energy distribution. According to The Organisation for Economic Cooperation and Development (OECD) data, there are instances where energy distribution losses are recorded very high causing a daunt in the energy production. For example in India, energy distribution losses are recorded at 19\% in 2014 against the world's average of $8.24 \%$ which is one of the highest as per the Industry standards (The Organisation for Economic Cooperation and Development, 2017). India needs to address these challenges radically within a shorter period of time as every loss is contributed to extra energy generation and thus extra affliction to the sustainable development. 


\subsection{HEI ENERGY MANAGEMENT}

Higher Educational Institutions are more responsible in terms of generating awareness among the society for sustainable development. The nature and involvement of HEI's generally provide a closer association with the society as their involvement in research \& development and consultancy activities (Cabrera \& Zareipour, 2011). HEI's are more directly involved in developing cultural, social, ethical, economic and environmental knowledge that will, ultimately, assist stakeholders in handling the various issues of modern life effectively. At the same time, partnerships among various educational institutions provide multicultural contexts in establishing and understanding diversity, working closely with various stakeholders and the community reflects and improve their activities in relation to education for sustainable development (Wals \& Jickling, 2002).

HEI's are expected to arrange and engage debates, research activities, using smart equipment on sustainable development that could influence environmental and social outcomes (Nasibulina, 2015). There are many initiatives taken by some of the HEI's recently in this regard including offering courses and programs that are inbuilt with the values of SD that need to continue to develop these skills in new forms of learning including stakeholder interactions at various stages to produce SD ready graduates for the benefit of mankind (Vare \& Scott, 2007).

Higher Education Institutions (HEIs) need to engage themselves with the objective of building a sustainable society for the benefit of current and future generations (Suryawanshi \& Narkhede, 2014). While the HEI's focus on establishing social responsibility and accountability processes, HEI's eventually develop processes that could guide them towards establishing sustainable community within and outside campuses. HEIs are organizational forms that groom employment relationship and management responsibility from the primary levels (Ahola, Ahlqvist, Ermes, Myllyoka \& Savola, 2009). HEIs are the best places to face the challenges caused by unsustainable development clusters in the society and could be the best tools to inculcate the values and importance of sustainable development due to their nature and close relationship with all the levels society including intellectuals and scholars 
to the general public (Chai-Arayalert \& Nakata, 2011). Sustainable development can only flourish with the commitment of organisational accountability and responsibility where the concepts, theory, and practice could be initiated and implemented as primary test cases at HEIs. Alternate energy sources and using smart equipment to reduce the energy demand is another option too that motivated this study. Applying smart equipment with smart methods eventually, provide a smart solution through education for sustainable development (Fettweis \& Zimmermann, 2008).

Malaysia is an emerging economy in South Asia and dynamic accomplice in this global awareness process for renewable energy. From the1970 onwards, Malaysia has introduced a range of regulatory measures to balance the goals of surging socioeconomic development with sustainable environment. The annual report for the year 2010 from the Economic Planning Unit-EPU in the Malaysian Prime Minister's office stated that Malaysia is moving towards high-income society and aspiring for developed nation status by 2020 with a knowledge-based society. At the same time, Malaysia understands that knowledge-based and high-income society has the responsibility of maintaining sustainable environment through the renewable energy and reinforcing its policies towards this objective.

HEIs in Malaysia are requested to consider designing their own smart grids (SG) by bearing in mind that some of the current options such as optimized congestion control, reliability, and break down costs that would work best for them when they opted for smart grids. They can customize the options that best suit their demand based on the needs of the institution, and on the requirements and nature of the energy source that the institution depends on. Along with that, they need to be aware of the factors while implementing the smart grids such as initial investment, return on investment (ROI), security matters, period of obsolescence and privacy. The estimated energy optimization percentages by smart grid implementations across countries such as China, India, and others are above 20\% (El-hawary, 2014). Most recently, regulators and governments are forced to control the CO2 emissions which is moving towards producing clean and green renewable energy. This is an excellent move which should be appreciated without skepticism. The produced green energy needs to be connected to the distribution networks in an efficient mechanism to 
maximize the benefits (Pahwa \& Venkata, 2011). In the Smart Grid Projects today, these technologies are being adopted into electric grid applications, involving devices at the consumer level through the transmission stage in order to make the electric system more responsive and flexible (Zhao et al., 2014).

\subsection{SMART GRIDS}

Alternate energy sources such as Solar, Wind or any other forms such as from Tidal or Hydro resources availability need to be studied with the HEI's data in terms of energy availability and consumption. Each KWH produced for HEI could then be connected to the main supply (Aghasian, Pourtaheri \& Ahmadizadeh, 2013). The cost of energy per MW production from highest to lowest are listed as follows with an exception of location: thermal with coal, thermal with natural gas, bio mass, solar thermal, nuclear, solar PV and hydroelectric and onshore wind. The Annual Energy Outlook 2015, by the US Energy Information Administration for the year 2015 states this clearly (Webber et al., 2006). It is interesting to see all the renewable sources are listed at the lower side and Fossil fuels are on the higher side with the additional issue of limited availability and irreplaceability. Figure 2 shows the cost of production in USD for the renewable energy per KW.

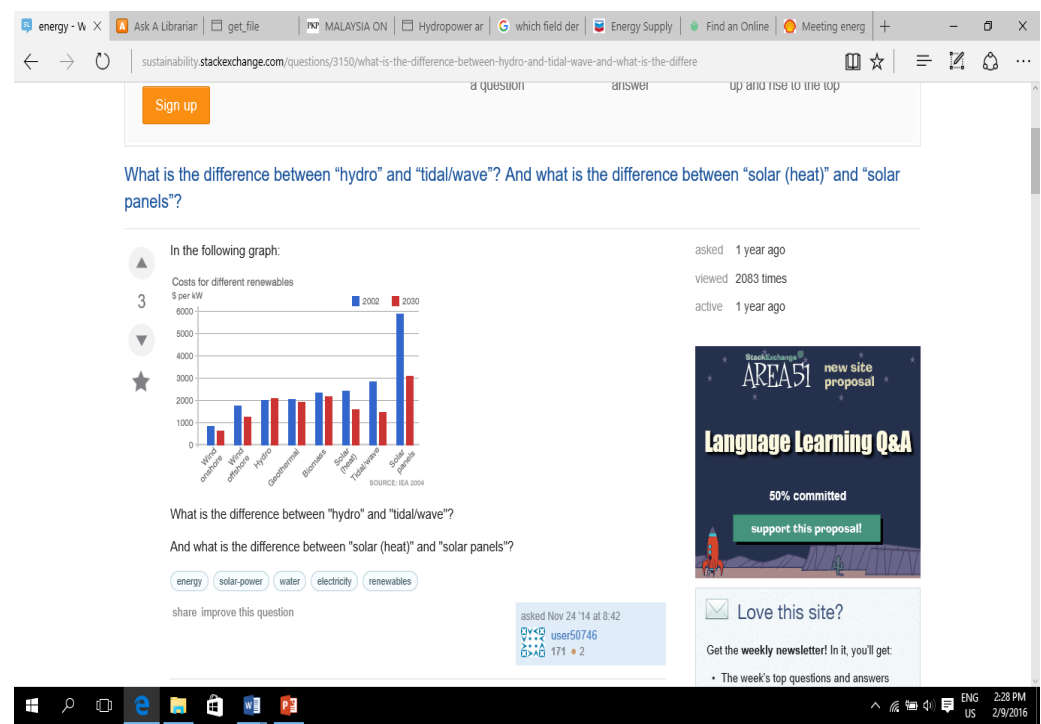

Figure 2. Cost of the production for Renewable Energy in USD per KW. 
Smart grid as defined by Electric Power Research Institute (EPRI) is "A Grid that incorporates information and communication technology into every aspect of electricity generation, delivery, and consumption in order to minimize environmental impact, enhance marketability, improve reliability, efficiency and service, and reduce costs." The main advantages of Smart Grids compared to previous traditional grids are its flexibility of allowing the consumers to play a role in optimizing the operation and provide a greater amount of information about the grid (Wakefield, 2011). It is obviously the appropriate time for HEIs to plan and switch their power supply systems to Smart Grids. Once they have started investing in the alternate energy source, they would reap the benefits it brings from the beginning as the cost of renewable energy generation such as the cost of solar panels are showing a consistent reduction since 1990. Figure 3 shows the cost reduction over the past 27 years and a projection for the coming decade-the graph clearly shows the great advantage of investing in alternative energy in terms of cost of energy production per watt.

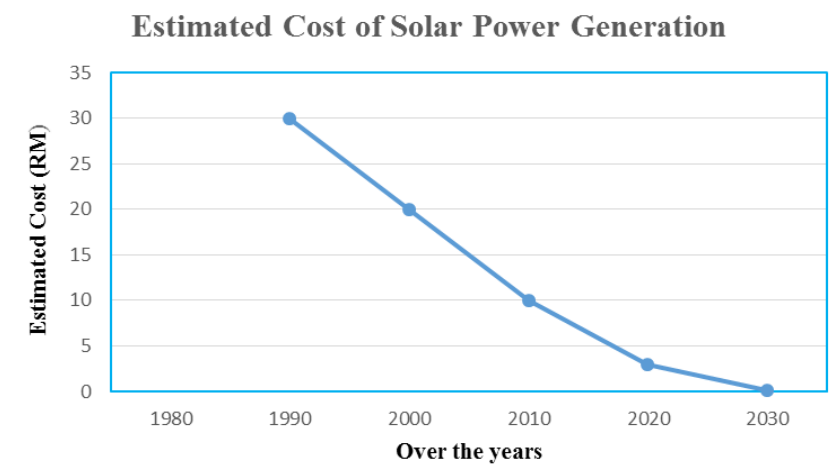

Figure 3. Solar power cost estimation over the years.

\section{IMPLEMENTATION METHODOLOGY}

The proposed research is being carried out in a private University College campus located in Mantin, Negeri Sembilan, Malaysia. The study details energy management within a campus that is built up area of 900,000 square feet with five academic blocks, one administration block, two blocks consisting 50 laboratories, nine lecture halls, and seven meeting rooms. The key factor in this study is to provide renewable 
energy that is suitable for the institution based on their scenario and opportunities available at its location and surroundings. Most importantly, it all depends on how this generated power is connected through a smart grid and to the distribution grid. To convert and maintain the campus as a green campus, a smart grid is proposed, as shown in Figure 4. The smart grid structure shown in Figure 4 could be used as a model Smart Grid for any HEI in Malaysia. In the proposed smart grid model, roof top solar panels and wind turbines are incorporated. The wind speed at the campus is recorded at an average of $5-10 \mathrm{~km} / \mathrm{h}$ throughout the year. This location is suitable for solar power generation as the average daily temperature ranges between 20-35c throughout the year that can easily produce 50W solar power (Mekhilef et al., 2012).

\subsection{THE REAL-TIME ENERGY MANAGEMENT EFFICIENCY}

Higher Education Campus' main energy consumptions are within the classrooms and laboratories. It is therefore crucial that these areas within a campus receive reliable and uninterrupted energy supply. The demands of the energy may vary between academic programmes depending on the nature of the programme and the equipment used to aid the teaching and learning processes. Technical and scientific programmes would require more energy particularly those with the use of heavy machinery for academic and research purposes (El-hawary, 2014).

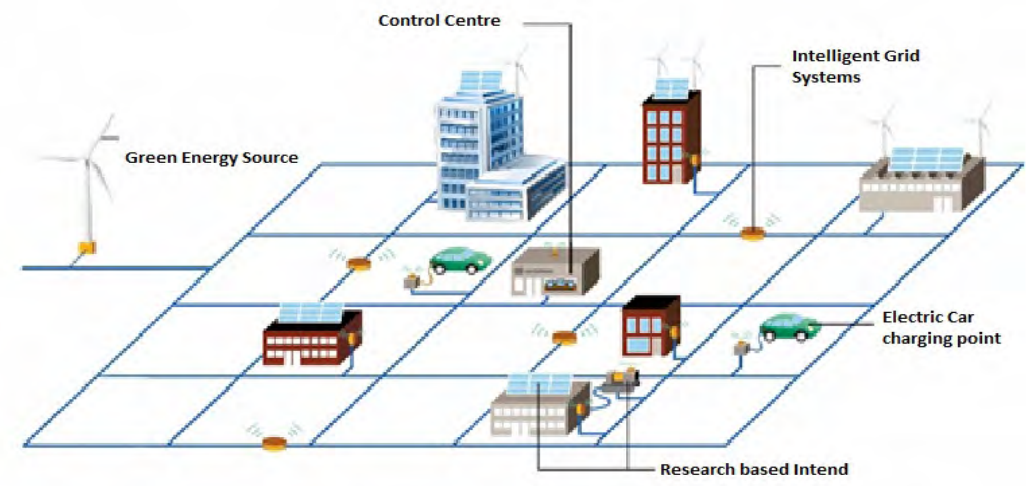

Figure 4. Typical structure of a smart grid for a HEI in Malaysia.

It is proposed that the particular HEI campus allocates Half-hour-ahead rolling optimization and a real-time control strategy are combined with fuzzy logic controller 
for surging optimization in producing high-efficiency energy distribution. A physical test platform has been established and was tested in an academic laboratory (a bench fitting lab) to observe the process in the campus.

\subsection{INTERNET OF THINGS (IOT) PROPOSAL FOR GRID OPERATION}

IoTs are also seen in the part of the total system that is operated in the smart grid system. Controlling the entire grid is possible from a remote location with IoT. Adjustments of power distributions from macro to micro is possible with IoT (Pahwa \& Venkata, 2011). The grid is evolving from the previous traditional one-way system, where power flows from centralized generation stations to consumers, to a platform that can detect, accept, manage, and control decentralized consumption and production resources. This allows power and information to flow as needed in multiple directions to keep the system in balance. As a result, utility executives are trying to determine which technologies merit precious capital resources (Zhao et al., 2014).

\subsection{TIMER CONTROLLED OPERATION FOR AIR-CONDITIONER}

The concept of the proposed circuit structure as shown in Figure 5 is to shut off the air conditioner every 1 hour after the unit is switched on.

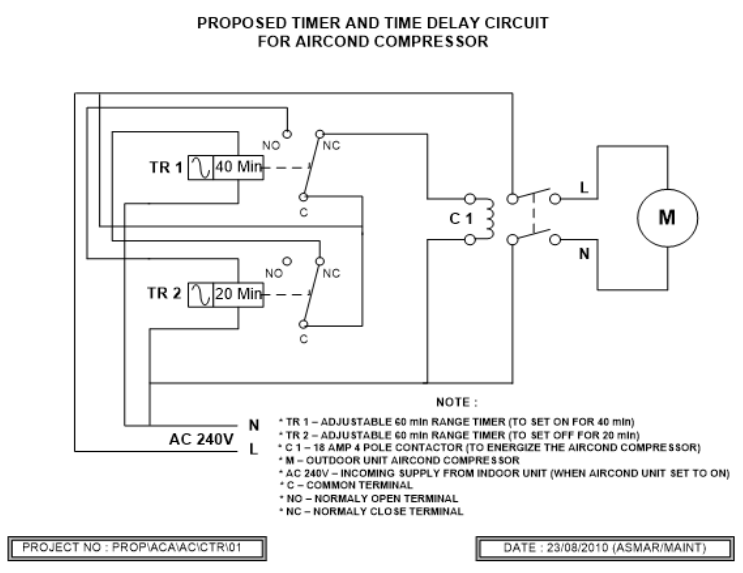

Figure 5. The proposed energy saver structure of an air-conditioner. 
Each time the air conditioner is switched back, the internal air conditioners IC board control will delay the outdoor unit (compressor) up to approximately 15 minutes in order to cool down the system. The user would have to switch on the air conditioner in order to continue its usage. As air conditioners have the highest energy consumption, this proposed method of smart timer structure in an air conditioning system would greatly save the HEI's energy consumption. The HEI's main energy consumption is for Air-conditioning which has been recorded at an average of $60 \%$ over the years.

\section{RESULTS AND DISCUSSIONS}

The two methods proposed for the ICT green campus are sensor controlled lighting arrangement in the laboratories and a timer-controlled air conditioner. These two techniques that were fixed at a nominal cost would fetch a lucrative ROI in less than a month while registering a commendable $40 \%$ in the laboratories, and $25 \%$ in air-conditioning energy optimization. The present HEI campus which is used in this study has a land area of about 200acres. The internal transport from the main entrance can be proposed into using bicycles for the students and for the staff using battery cars. This shows that ROI is expected within a year. There are many other possibilities such as fluorescent tubes could be replaced by LED lamps which can optimize a $30 \%$ reduction in the energy reduction.

\subsection{REAL TIME ENERGY MANAGEMENT LAYOUT}

The main power consumption for the month of May 2017 was $60 \%$ due to the air conditioning. 20\% were for lighting and desk stations, while laboratories were around $11 \%$. For the benefit of this research, each lab was fitted with a remote-controlled sensor that activates whenever there is a room in use. A motion sensor is fitted to each row of tables which controls the usage depending on its occupancy. This smart device is also able to differentiate a real user from a passerby as the motion detector is initiated 3 minutes after the machine is switched on. For lecture halls, the seat occupancy is controlled by the class management team that determines the allocation of the room and the seats inside the auditorium. The electricity consumption from the 
pre-and post-implementation for each of the venues are calculated on a daily basis. In the proposed study, it is assumed that in an 8-hour working day, 8 samples of data between a 15 minutes interval is collected which will result in at least 120 minutes or 2 hours of outdoor off-duty. This would mean no electricity consumption per 1 unit air conditioner per day. With this calculation record, the energy consumption of an air conditioner without a timer and with a timer is shown in Tables 1 and 2.

Table 1. HEl's Energy Consumption of an Air Conditioners without Timer.

\begin{tabular}{|c|c|c|c|c|c|c|c|}
\hline \multirow[b]{2}{*}{$\begin{array}{c}\text { AIRCOND } \\
\text { H/P }\end{array}$} & \multicolumn{7}{|c|}{ ELECTRICAL CONSUMPTION CHARGE CALCULATION FORMULA (NORMAL) } \\
\hline & KW & TARIFF & $\begin{array}{c}\text { RATE/ } \\
\text { HR } \\
\text { (RM) }\end{array}$ & $\begin{array}{c}X 8 \text { HRS } \\
\text { (RM) }\end{array}$ & $\begin{array}{c}\text { X } 20 \\
\text { DAYS } \\
\text { (RM) }\end{array}$ & $\begin{array}{l}\text { X TOTAL } \\
\text { (AC) }\end{array}$ & $\begin{array}{l}\text { AMOUNT } \\
\text { (RM) }\end{array}$ \\
\hline 1.0 & 0.746 & 0.43 & 0.32 & 2.56 & 51.20 & 9 NOS & 460.80 \\
\hline 1.5 & 1.118 & 0.43 & 0.48 & 3.84 & 76.80 & 4 NOS & 307.20 \\
\hline 1.8 & 1.342 & 0.43 & 0.58 & 4.64 & 92.80 & $16 \mathrm{NOS}$ & $1,484.80$ \\
\hline 2.0 & 1.491 & 0.43 & 0.64 & 5.12 & 102.40 & $50 \mathrm{NOS}$ & $5,120.00$ \\
\hline 2.5 & 1.864 & 0.43 & 0.80 & 6.40 & 128.00 & 265 NOS & $33,920.00$ \\
\hline 2.8 & 2.087 & 0.43 & 0.90 & 7.20 & 144.60 & 14 NOS & $2,016.00$ \\
\hline 3.0 & 2.237 & 0.43 & 0.96 & 7.68 & 153.60 & 258 NOS & $39,628.80$ \\
\hline 3.5 & 2.609 & 0.43 & 1.12 & 8.96 & 179.20 & $18 \mathrm{NOS}$ & $3,225.60$ \\
\hline \multirow[t]{2}{*}{5.0} & 3.725 & 0.43 & 1.60 & 12.80 & 256.00 & 64 NOS & $16,384.00$ \\
\hline & & & & & & $\begin{array}{l}\text { TOTAL } \\
\text { COST }\end{array}$ & $\begin{array}{c}\mathrm{RM} \\
102,547.20\end{array}$ \\
\hline
\end{tabular}

Table 2. HEl's Energy Consumption of an Air Conditioners using Timer.

\begin{tabular}{|c|c|c|c|c|c|c|c|}
\hline \multirow{2}{*}{$\begin{array}{l}\text { AIRCOND } \\
\quad \text { H/P }\end{array}$} & \multicolumn{7}{|c|}{$\begin{array}{l}\text { ELECTRICAL CONSUMPTION CHARGE CALCULATION FORMULA (TIMER } \\
\text { CIRCUIT) }\end{array}$} \\
\hline & KW & TARIFF & $\begin{array}{l}\text { RATE/ } \\
\text { HR (RM) }\end{array}$ & $\begin{array}{l}\text { X } 6 \text { HRS } \\
\text { (RM) }\end{array}$ & $\begin{array}{c}X 20 \\
\text { DAYS } \\
\text { (RM) }\end{array}$ & $\begin{array}{l}\text { X TOTAL } \\
\text { (AC) }\end{array}$ & $\begin{array}{l}\text { AMOUNT } \\
\text { (RM) }\end{array}$ \\
\hline 1.0 & 0.746 & 0.43 & 0.32 & 1.92 & 38.40 & 9 NOS & 345.60 \\
\hline 1.5 & 1.118 & 0.43 & 0.48 & 2.88 & 57.60 & 4 NOS & 230.40 \\
\hline 1.8 & 1.342 & 0.43 & 0.58 & 3.48 & 69.60 & 16 NOS & $1,113.60$ \\
\hline 2.0 & 1.491 & 0.43 & 0.64 & 3.84 & 76.80 & 50 NOS & $3,840.00$ \\
\hline 2.5 & 1.864 & 0.43 & 0.80 & 4.80 & 96.00 & $265 \mathrm{NOS}$ & $25,440.00$ \\
\hline 2.8 & 2.087 & 0.43 & 0.90 & 5.40 & 108.00 & 14 NOS & $1,512.00$ \\
\hline 3.0 & 2.237 & 0.43 & 0.96 & 5.76 & 115.20 & 258 NOS & $29,721.60$ \\
\hline
\end{tabular}




\begin{tabular}{|c|c|c|c|c|c|c|c|}
\hline \multicolumn{7}{|c|}{ ELECTRICAL CONSUMPTION CHARGE CALCULATION FORMULA (TIMER } \\
CIRCUIT) \\
$\begin{array}{c}\text { AIRCOND } \\
\text { H/P }\end{array}$
\end{tabular}

The Corridors are fitted with two 40W Fluorescent tubes within a distance of $15 \mathrm{ft}$. Each $(40 x 40) f t$ laboratory is fitted with 8 sets of fluorescent tube lights. There are two $100 \mathrm{~W}$ pedestal industrial fans that are connected along with two units of $2.5 \mathrm{hp}$ air-conditioners. Normal working hours are 8 AM to 4:30 PM. Average operating hours in a day are 5 hours. When a laboratory is in operation, the consumption within the laboratory totals up to 5700W (8X80W + 2X200 + 940X2.5X2). We have fitted the sensor control circuit shown in Figure 3 with an initial cost of RM700. This circuit is tested for an hour usage in the bench-fitting workshop and it does not draw any other energy other than lighting and air-conditioning.

From Tables 1 and 2, it is observed that a total of RM 25,636.80 can be saved. This is equivalent to $25 \%$ of savings every month by using this idea of delaying every single air conditioner for up to 2 hours daily in its operation. Table 3 shows the total airconditioners required and its costs for the entire academic operation. Table 4. Shows the electrical items that are purchased for constructing the control module in an air conditioner at the HEI.

Table 3. Total Air Conditioners required and its cost.

\begin{tabular}{|c|c|c|c|c|}
\hline PHASE & $\begin{array}{c}\text { AREA } \\
\text { COVERED }\end{array}$ & $\begin{array}{c}\text { TOTAL } \\
\text { AIRCOND }\end{array}$ & $\begin{array}{c}\text { COSTING in } \\
\text { RM }\end{array}$ & REMARKS \\
\hline 1 & Block A1 Till A5 & 296 Unit & $16,537.00$ & \\
\hline 2 & Admin Block & 226 Unit & $12,317.00$ & \\
\hline 3 & Block B1 \& B2 & 176 Unit & $9,592.00$ & \\
\hline & TOTAL & $\begin{array}{c}698 \text { Unit + } \\
\text { Extra }\end{array}$ & $38,446.00$ & + + RM 109.00 \\
\hline & GRAND TOTAL & 700 Unit & $38,555.00$ & \\
\hline
\end{tabular}


Table 4. Control modules cost for an Air Conditioners.

\begin{tabular}{|c|l|c|c|c|}
\hline NO & ITEM DESCRIPTION & $\begin{array}{c}\text { ESTIMATE } \\
\text { PRICE (RM) }\end{array}$ & QUANTITY & $\begin{array}{c}\text { TOTAL PRICE } \\
\text { (RM) }\end{array}$ \\
\hline 1. & 60 Minute Timer Relay (jkn) & $48.00 / \mathrm{Pc}$ & $700 \mathrm{nos}$ & $33,600.00$ \\
\hline 2. & 8 Pin Socket Base & $6.50 / \mathrm{Pc}$ & $700 \mathrm{nos}$ & $4,550.00$ \\
3. & Socket Railing (Alluminium) & $15.00 / \mathrm{Meter}$ & $15 \mathrm{pcs}$ & 225.00 \\
\hline 4. & Pvc Black Tape & $0.60 / \mathrm{Pc}$ & $50 \mathrm{rolls}$ & 30.00 \\
\hline 5. & Connector & $1.50 / \mathrm{Pc}$ & $100 \mathrm{pcs}$ & 150.00 \\
\hline & Grand Total & & & $\mathbf{R M ~ 3 8 , 5 5 5 . 0 0}$ \\
\hline
\end{tabular}

This simple mechanism and its installation worked extremely well for a period of 1 month with an average of $25 \%$ reduction in the energy usage and its direct cost. The graph shown in Figure 6 explains the monthly energy consumption distribution for the entire campus.

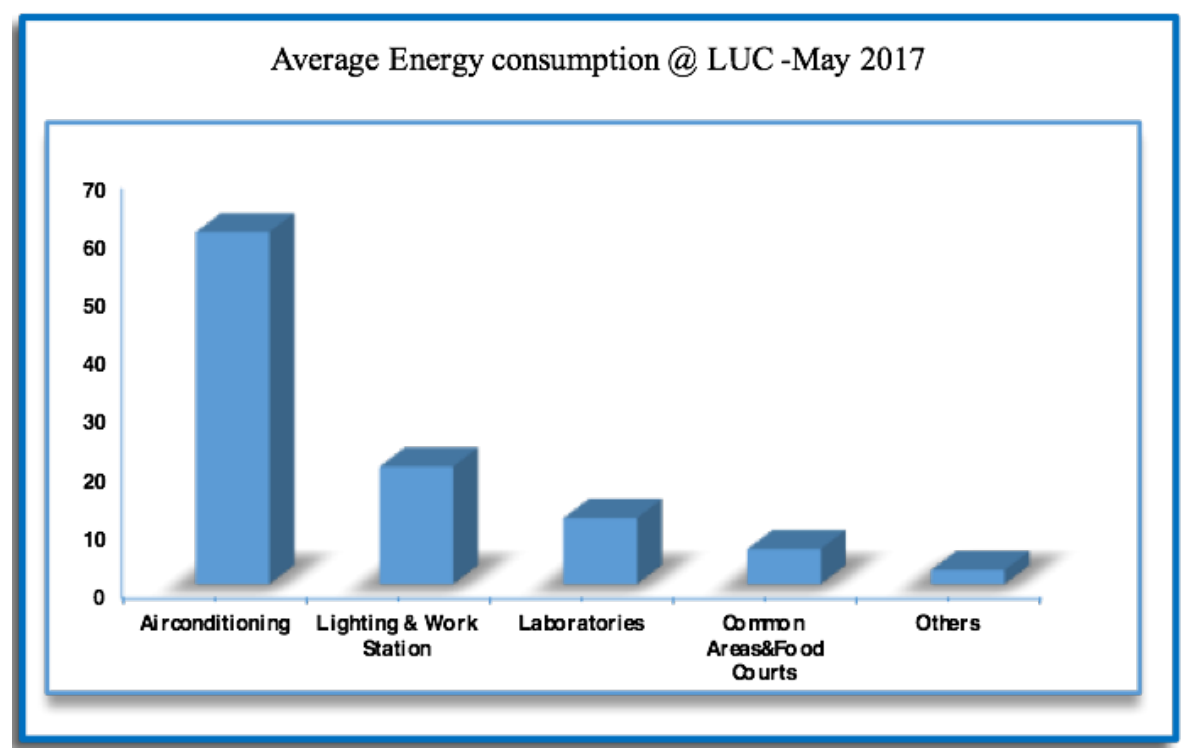

Figure 6. The monthly energy distribution of one HEI (Linton University College).

The motion detection sensors assisted in regulating and optimizing the usage as per classroom occupancy. This new technique proposed in the new circuit diagram has been used to continue observations for a period of one month with full capacity, partial capacity and within lower occupancy classrooms. The lower occupancies have a difference of up to $1700 \mathrm{~W}(70 \%)$ reduction and medium occupancy has $3130 \mathrm{~W}(45 \%)$ while the full occupancy has $600 \mathrm{~W}(10 \%)$. The difference from these 
three scenarios make an average of $40 \%$ reduced consumption. The same circuit setup holds good for a classroom and lecture halls with a difference in the number of equipment fitted. When ROI was calculated for the RM700 spent, the investment was returned within a month. The energy savings for the rest of the days in the year and in the future, will complement its usage. Further research is however needed especially in the areas of synchronizing with smart grid management and IoT. Such a paradigm change needs to begin from academic institutions in order to be forged by the society for the betterment of life and to fight against global warming.

\section{CONCLUSION}

Energy production and distribution are equally important and with the new technologies on board, the distribution with the help of smart grid has become resilient and efficient. The two methods proposed which are the timer-controlled air conditioner and motion-sensor-controlled lighting arrangements in the laboratories have proved that energy saving is $40 \%$ in average with the RoI within a month when compared to the previous energy costs. Similarly, Malaysian HEIs should focus on the possible ways to generate power, considering and incorporating the scale and technology that is convenient and available for the institution, and to integrate them with the distribution network with the help of smart grids that are monitored by ICT to realize the Green ICT Campus for better, greener world.

\section{REFERENCES}

Aghasian, E., Pourtaheri, H., \& Ahmadizadeh, E. (2013). An Investigation on Current Situation of Green ICT in University Technology Malaysia-Based on Stage of Growth and Monitoring Green Technology Standardization Criteria. Open International Fournal of Informatics (OIfI), 1(1), 18-28. Retrieved from: http:// apps.razak.utm.my/ojs/index.php/oiji/article/view/95

Ahola, J., Ahlqvist, T., Ermes, M., Myllyoka, J., \& Savola, J. (2009). ICT for Environmental Sustainability. VTT Research Notes. 
Gabrera, D.F., \& Zareipour, H. (2011). A Review of Energy Efficiency Initiatives in Post-Secondary Educational Institutes in Proceedings of the First International Conference on Smart Grids, Green Communications and IT Energy-aware Technologies. Paper presented at First International Conference on Smart Grids, Green Communications and IT Energy-aware Technologies.

Chai-Arayalert, S., \& Nakata, K. (2011) The Evolution of Green ICT Practice: UK Higher Education Institutions Case Study. In Proceedings of the 2011 IEEE/ ACM International Conference on Green Computing and Communications, 220-225. Paper presented at IEEE/ACM International Conference on Green Computing and Communications. IEEE Computer Society.

Du Pisani, J.A. (2006). Sustainable development-historical roots of the concept. Environmental Sciences, 3(2), 83-96. doi:https://doi. org/10.1080/15693430600688831

El-hawary, M.E. (2014). The Smart Grid - State-of-the-art and Future Trends. Electric Power Components and Systems, 42(3-4), 239-250. doi: https://doi. org/10.1109/MEPGON.2016.7836856

Fettweis, G. P., \& Zimmermann, E. (2008). ICT Energy Consumption-Trends and Challenges. In Proceedings of the 11th International Symposium on Wireless Personal Multimedia Communications (WPMC'08). Paper presented at 11 th International Symposium on Wireless Personal Multimedia Communications (WPMC'08). Lapland, Finland.

Howlett, G., Ferreira, J.A.L., \& Blomfield, J.M. (2016). Teaching Sustainable Development in Higher Education: Building Gritical Reflective Thinkers through an Interdisciplinary Approach. International Journal of Sustainability in Higher Education, 17(3), 305-321. doi: https://doi.org/10.1108/IJSHE-07-2014-0102

Mekhilef, S., Safari, A., Mustaffa, W.E.S., Saidur, R., Omar, R., \& Younis, M.A.A. (2012). Solar Energy in Malaysia: Current State and Prospects. Renewable and Sustainable Energy Reviews, 16(1), 386-396. doi: https://doi.org/10.1016/j. rser.2011.08.003 
Ministry of Higher Education Malaysia. (2016). Makro Institusi Pendidikan Tinggi, 1. Retrieved from: http://www.mohe.gov.my/en/download/awam/ statistik/2016-statistik

Nasibulina, A. (2015). Education for Sustainable Development and Environmental Ethics. Procedia-Social and Behavioral Sciences, 214, 1077-1082. doi: https://doi. org/10.1016/j.sbspro.2015.11.708

Pahwa, A., \& Venkata, S.S. (2011). Preparing the Workforce for Smart Distribution Systems. In Proceedings of IEEE PES Innovative Smart Grid Technologies Asia (ISGT). Presented at of IEEE PES Innovative Smart Grid Technologies Asia (ISGT), 1-3. Perth, Australia.

Ritchie, H., \& Roser, M. (2017). $\mathrm{CO}_{2}$ and other Greenhouse Gas Emissions. Retrieved from: https://ourworldindata.org/co2-and-other-greenhouse-gas-emissions

Singh, S. (2017). How long will fossil fuels last? Retrieved from: https:/ / www.businessstandard.com/article/punditry/how-long-will-fossil-fuels-last-115092201397_1. html

Suryawanshi, K.Y., \& Narkhede, S. (2014). Green ICT at Higher Education Institution: Solution for Sustenance of ICT in Future. International fournal of Computer Applications, 107(14), 35-38. doi: https://doi.org/10.5120/18823-0237

The Organisation for Economic Gooperation and Development. (2018) OECD work on Climate Action. Retrieved from: http:/ /www.oecd.org/environment/ action-on-climate-change

Vare, P., \& Scott, W. (2007). Learning for a Change: Exploring the Relationship between Education and Sustainable Development. Fournal of Education for Sustainable Development, 1(2), 191-198. doi: https://doi.org/10.1177/097340820700100209

Wakefield, M.P. (2011). Smart Distribution System Research in EPRI's Smart Grid Demonstration Initiative. IEEE Power and Energy Society General Meeting, 1-4. doi: https://doi.org/10.1109/PES.2011.6039386 
Wals, A.E.J., \& Jickling, B. (2002). "Sustainability" in Higher Education: From Doublethink and Newspeak to Critical Thinking and Meaningful Learning. International Fournal of Sustainability in Higher Education, 3(3), 221-232. doi: https:// doi.org/10.1016/S0952-8733(02)00003-X

Webber, G.A., Roberson, J.A., McWhinney, M.G., Brown, R.E., Pinckard, M.J., \& Busch, J.F. (2006). After-hours Power Status of Office Equipment in the USA. Energy, 31, 2487-2502. doi: https://doi.org/10.1016/j.energy.2005.11.007

Zhao, J., Wang, C., Zhao, B., Lin, F., Zhou, Q., \& Wang, Y. (2014). A Review of Active Management for Distribution Networks: Current Status and Future Development Trends. Electric Power Components and Systems, 42(3-4), 280-293. doi: https://doi.org/10.1080/15325008.2013.862325 